\title{
The Management of Complaints in Slovene Public Administration
}

\author{
Janez Stare, Barbara Gruden and Polonca Kovač
}

University of Ljubljana, Faculty of Administration, 1000 Ljubljana, Gosarjeva ulica 5,
janez.stare@fu.uni-lj.si, barbara.drnovsek@gmail.com, polona.kovac@fu.uni.lj.si

The Slovene public administration is part of the broader social system, therefore it must be responsive and proactive. The instrument of complaint in the administrative procedure, and wider in the context of the entire administrative management, is very helpful to public administration for tracking social changes and should therefore be seen as a form of constructive criticism. On the basis of user complaints regarding its services or the parties to the administrative procedure, the public administration must learn permanently and, as learning organisation, must incorporate its findings into future practice. The starting point of this contribution is the problems of the complaint in the narrow sense - customer dissatisfaction with the functioning of the public administration or arising from the fact that one of the characteristics of the administrative procedure or other services is the direct contact between the customer and the provider of the service. With this approach, the public administration will develop part of an integral system of quality and excellence that underlines the meaning of satisfaction of (all) the users of public services.

Key words: complaint, public administration, Slovenia, customer, administrative procedure, administrative management

\section{Upravljanje pritožb v slovenski javni upravi}

Slovenska javna uprava je del širšega družbenega sistema. Zato mora delovati odzivno in celo proaktivno. Instrument pritožbe $v$ upravnem postopku in širše $v$ okviru celotnega upravnega poslovanja je javni upravi pri sledenju družbenim spremembam v pomoč in bi ga tako morala jemati kot obliko konstruktivne kritike. Javna uprava se mora na podlagi pritožb uporabnikov njenih storitev oz. strank $v$ upravnih postopkih učiti in kot učeča organizacija nauke vgraditi v bodočo prakso. $V$ prispevku izhajamo iz tistih problemov pritožbe $v$ ožjem smislu kot nezadovoljstva stranke, ki se nanašajo na delovanje javne uprave oz. izhajajo iz dejstva, da je ena izmed značilnosti upravnega postopka oz. druge storitve prav neposreden stik med stranko in izvajalcem storitve. S tovrstnim pristopom bo javna uprava razvila del celovitega sistema kakovosti oz. odličnosti, ki poudarja pomen zadovoljstva (vseh) uporabnikov javnih storitev.

Ključne besede: pritožba, javna uprava, Slovenija, uporabnik/stranka, upravni postopek, upravno poslovanje

\section{Introduction}

The establishment of a modern state requires the formation of a public administration that is capable of promoting changes, directing operations and following the expectations and acts of the society and its individuals. Its function is becoming more and more important and is therefore under the critical supervision of the public and the customers (all interested citizens). The reasons for this lie in structural changes in the public administration (partly as a consequence of a revised functionality based on the types of organisation), technological changes, changing values and the development of society in general. In respect to the latter, the role of public administra- tion is as promoter rather than inhibitor of the competitiveness of the national economy in the EU and worldwide.

The Slovene legal system does not provide a uniform definition of the notion of public administration (Kovač, 2006). As regards the handling of complaints, the general management of administrative procedures and the implementation of the administrative tasks of the authorities, the public administration could be defined, in terms of functionality or process, as a part of the process of public management carried out at the operative/expert level. Public administration covers decisions and implementations at the instrumental level, i.e. issuing or enforcing the general and individual implementing acts, since the basic functions of the public administration are the preparation of legal bases for the drafting of policies and the intensive implementation of the public policies adopted. Conse- 
quently, the structural definition of the public administration as the core of the administrative system consists of the bodies of the public administration, such as the ministries (15), the bodies within the ministries (e.g. offices, administrations and inspectorates, a total of around 50) and administrative units (58), as well as government offices (16) to a certain extent. The public administration also covers the municipal administrations and public authority holders at the national and the municipal levels who carry out the administrative tasks, either independently or in the scope of the public services. In this sense, Article 1 of the General Administrative Procedure Act (ZUP, Official Gazette of the Republic of Slovenia, no. 24/2006-UPB2, 105/2006-ZUS-1) stipulates that the bodies of the public administration, the municipal administration and the public authority holders, as well as non-administrative state bodies that decide in the administrative matters (i.e. perform one of the basic administrative tasks), are all considered administrative bodies.

The critical attitude of the public is related to the implementation of administrative procedures and the adoption of decisions on the subject of the procedure. Also, more and more often, it relates to the general attitude of the administration towards the management of customers of the administrative procedures or, more broadly, the users of its services. ${ }^{1}$ In public criticism, the public administration is (too) often seen as a bureaucratic system: far removed from the people, introvert, stubborn, self-willed, unpleasant and unresponsive. The reasons for such an opinion are different and difficult to determine, due to their complexity. Nevertheless, they can be classified into the following groups:

- incomplete, inconsistent and rapidly changing legal bases for the public administration work;

- actual mistakes, insufficiencies and the slow enforcement of the administrative procedures and other administrative services;

- the growing demand of the society and a more critical public;

- a general impression is that the functioning of the state, of the economy and of each individual often depends on the speed, accuracy and appropriateness of the reactions of the apparently anonymous and "nontransparent" parts of the administration.

Regarding decision-making, the deadlines in the Slovene administrative practice are problematic (over-due time, especially in tax and the construction matters). The adoption of decisions within the set deadlines and backlogs is monitored through the Rules on the keeping of records of administrative procedures (Rules, Official Gazette of the Republic of Slovenia no. 18/2003, 7/2006).
The abovementioned criticism is frequently intensified through the direct relations of the users with the public administration, which is why an appropriate attitude must be maintained towards the users of public services and the handling of complaints, since this is reflected in the public image of the public administration. The organisations have set up different techniques for tackling these problems. The organisations of the public administration in charge of establishing the system of excellence, quality or integration of the principles of the new public management into their operations, resolve the issues of handling complaints or customer relationships with the help of the ISO quality standards, improvements based on the CAF (Common Assessment Framework) and EFQM models of excellence and the Balanced Scorecards system (more in Kovač and Kern, 2005, and the web pages of the of Public Administration).

Designing the balanced scorecards covers the recognition and, especially, the assurance of appropriate knowledge, skills and other resources that will facilitate (besides the achievement of financial goals and goals in the area of internal process management, growth and learning) the efficient implementation of the most important processes for achieving customer satisfaction. Individual indicators are defined, which describe the customer's aspect from different points of view. Nemec (2007:5) points out that, from the point of view of the customers, the indicators of the administrative unit are as follows:

- the customer satisfaction index,

- resolving matters within the deadlines,

- the speed of resolving matters,

- the number of visits to the administrative unit concerning a single matter,

- quality costs - the costs to the attitude and work of the employees arising from the customers' complaints,

- the level of customer information, etc.

\section{Complaints}

The complaint is justified in both the public and the private sector but there can be no differences regarding the public interests to be protected. Conversely, we need to point out the significant difference in the treatment of complaints submitted by customers from the public and the private sector. If the customers are not satisfied, there is more likelihood that complaints will lodged in spite of quality administrative services, since the protection of public benefit has priority over the partial interest of a customer. In resolving the complaints of the customers and

\footnotetext{
${ }^{1}$ Slovene legislation uses different expressions for users of public administration. For instance, there is the word »customer « in ZUP, but it is »user « in subsidiary legislation, »citizen« in some cases, or even »client«. But the authors decided to use only one word in this article so as to avoid confusing the readers, and that is a "consumer". The same goes for a »complaint « or an »appeal«, the second being used in administrative procedures on the basis of ZUP, while the first on the other hand is used as a broader term. However, to support the main finding of the authors regarding the common message of complaints and appeals as feedback to the public administration, we use only one term in the whole article - and that is a "complaint", which also covers ZUP appeals.
} 
adopting administrative decisions, the administrative bodies must take care that the customers do not exercise their rights to the detriment of the rights of others and against the public good, as stipulated by law or by other regulations (ZUP, Article 7 ). The right to complain against an authority decision is granted by the Constitution of the Republic of Slovenia (Official Gazette of the Republic of Slovenia, no. 42/1997, 66/2000, 24/2003, 69/2004, 69/2004, 69/2004, 68/2006; Article 25, the right to (efficient) legal remedy, and Article 22, the equal protection of rights) and is one of the basic principles of the administrative procedure.

Sometimes the complaint can be seen as a "collective action that indicates the joint efforts of a group of persons towards a common goal. It constitutes a sub-variety of social action. Action implies intentionality and is thereby distinguished from mere behaviour, which is not necessarily goal-oriented (Bader, 1991: 67). Collective action, despite being individual action in practice (Luhmann [1984] 1988: 273 ), is a form of social action and hence "it can be oriented at the past, present or expected behaviour of others" (Weber [1921] 1978: 11)" (König, 2005: 9).

The complaint can be seen as an expression of the dissatisfaction of users/customers as regards the enforcing or performing of the task of public administration with the aim of improving the situation. In the broader context, the complaints concern the alignment of the functioning of the administration or the way in which the "supply" of the administration is interconnected. In this sense, the complaints themselves do not merely represent a subsequent reaction of the users but also the annoyance of those who feel affected by the planned or the actual functioning of the administration. In a more narrow sense, a complaint is viewed as an expression of dissatisfaction, related to the result of the administrative procedure, the process of the preparation or performance of administrative services (other than procedural) and, in this relation, also the direct relationship with the customers. The basis for this contribution is the problems of the complaint in the narrow sense, i.e. as customer dissatisfaction, which is related to the functioning of the public administration and arises from the fact that one of the characteristics of the administrative procedure or other services is the direct contact between the customer and the provider of the service.

\section{The Starting Points for Establishing the Attitude Towards a Complaint}

Regarding the handling of a complaint, certain factors can be highlighted that determine the establishment of an attitude towards complaint handling.

\subsection{The Complaints Mechanism}

The Constitution of the Republic of Slovenia stipulates that everybody has the right to complain or use another legal remedy against a decision passed by a court or any other state body, local authority or public authority holder concerning an individual's right, duties or legal benefits. The user has the right to lodge a petition against the work of the public administration and, contrary to the private sector, the administration is obliged to study the concrete matter and adopt an appropriate corrective measure.

It was established through experience, that the consumers of public services more and more often refer to their rights to complain (data is available only for some fields or units, but include complaints within administrative procedures or other administrative handling, http:// upravneenote.gov.si/). The increase in the number of complaints should stimulate those responsible to reconsider the efficiency and effectiveness of their work. Considering the impact the complaints have on the burden of the officials, their working hours and the operating costs, it would be sensible to adopt a regulation on the efficient handling of complaints. Quality communication with dissatisfied users should be formulated and a professional dialogue created that would build on previous errors.

Contrary to the private sector, a user has access to a series of complaint mechanisms or complaint communication channels through which they can express their dissatisfaction with the functioning of the public administration or can try to change it. These include the influence on politics and the leading politicians (elections or direct influence on party leaders, members of parliament or councillors), co-operation in the institutionalised forms of citizen participation (local assembly), people's initiative, complaints to the people or departments whose primary task is to resolve general or special issues concerning the functioning of the state or public administration (ombudsman), the development of e-administration (e.g. submitting initiatives to eliminate administrative barriers, see the websites of the Ministry of Public Administration (2007a, 2007b) and the websites of the Administrative units (2007), the project on the removal of administrative barriers), etc.

Among the latest initiatives, we should highlight the measurement of user satisfaction with public services in accordance with Article 17 of the Decree on administrative operations (UUP or Decree, Official Gazette of the Republic of Slovenia nos. 20/2005, 106/2005, 30/2005, $86 / 2006,32 / 2007,63 / 2007)$. In a series of provisions, in which it summarised the previously applicable Decree on the method of operations of public administration bodies, the Decree is a kind of citizen charter that lays down the minimum quality standards in the relations between the administration and the customers. The Decree stipulates that, as of 2001, the public administration bodies must annually assess customer satisfaction according to the established methodology (opinion polls) and, as of 2006, must measure the situation in the framework of the system called the Quality Barometer on a monthly basis. The Quality Barometer's questionnaire contains an assessment of four parameters of the body's operations:

- the quality work of the official(s),

- the attitude of the official(s), 
- the speed of the work performed and

- the appropriate organisation and accessibility of the body.

All data is available to the general public; improvements are sought as a consequence of the corrective measures for the state presented.

Based on the Decree, each body of the public administration must provide a book of praise and complaints (Decree, Article 15). The book, which must be kept in the reception room of the public administration body must be reviewed weekly by the head of the public administration body. The review must be confirmed by a signature in the book and answers must be provided to submitted requests. The Decree further stipulates a series of so-called operating standards for relations with the customers/users, such as:

- the customers' right to make a note in the book and the official address of the administrative inspection, which is the internal supervisory body over the implementation of the Decree, must be displayed in a visible manner in the business premises used for accepting customers

- each organisation must have its own advisor to assist customers (Decree, Article 7),

- the users must be provided with well-structured general information on the operations of the organisation (Decree, Articles 6 to 9) and the information in concrete procedures (Decree, Articles 19 and 20),

- the organisation must comply with the deadlines set for issuing decisions or providing services (Decree, Articles 8,15,18 and 21),

- the minimum scope and schedule of working and office hours must be determined. These have been considerably increased in the amended decree of May 2007 (Decree, Articles 52-60 and related Articles),

- the organisation must have referral tables, marks, bulletin board, etc. (Decree, Articles 63 to 68),

- the public administration must exchange data from the official records; the customers are only asked to supplement their applications if the missing data cannot be obtained otherwise,

- in operations, the organisation must distinguish between the management of documents and the reception of the customers (separate the main and the reception offices), etc.

The increased set of standards creates new possibilities for complaints about the operations, which must nevertheless be seen as opportunities for improvement and upgrade without interfering with the benefits of the public or the rights of others.

\subsection{Complaints as an Instrument of Quality Control}

In the sense of assuring quality, complaints represent an instrument of quality control. The administration does not operate on the market and thus (as opposed to the private sector) lacks the capacity of a feedback mechanism. Therefore, it also has fewer possibilities for assessing the appropriateness of the range of services provided to the users of public services. It is therefore essential that the administration obtains feedback related to its operations. This includes appropriate communication stimulated by the users and in most cases relating to the content of the information on the complaints submitted by the customers concerning the quality of services.

We should also mention the fact that a large part of the services provided by the public administration is organised in the form of different activities in the form of personal interaction between the official and the customer. Nemec (2001: 1) believes that it is the direct contact through which the customer recognises quality of the service, not only on the basis of the final result but also on the basis of the service's progress. The key issue here is identifying those elements of providing an administrative service that, besides the measurable or normative quality (such as the accuracy of the document, timeliness of issue, resolving of complaint, etc.), also impact the customer's satisfaction.

This leads us to conclude that the quality of services in public administration greatly depends on the person entrusted with the implementation of the administrative task, as well as the type and scope of participation on the part of the users of public services. This means that the result of the services cannot always be completely standardised or guaranteed. Therefore, the standardised quality control measures are not ultimately set, rather they are merely determined in a limited scope. With a reasonable analysis of information, the established complaints handling system could provide an important contribution to filling the gap in the field of service quality control in the public administration.

The CAF 2006 model defines user (i.e. customer or citizen) satisfaction using indicators 6.1 and 6.2 , establishing whether the organisation takes appropriate systemic care to achieve the results of customer satisfaction and whether the goals are achieved, and whether the organisation takes appropriate systemic care to achieve the indicators used for measuring, focused on the users. For the first indicator (out of a total of 28 in the whole model), a positive answer is supported by examples such as (EIPA, 2006: 20):

- The results on the general image of the organisation (e.g. the friendliness and justness of actions, the flexibility and the ability to resolve individual situations);

- The results of integration and co-operation;

- The results regarding accessibility (e.g. opening and waiting times and one-stop-shops);

- The results related to the products and services (e.g. quality, reliability, compliance with quality standards, processing time and quality of advice provided to the customers).

The examples under indicator 6.2 - i.e. the indicators of the general image of the organisation that explicitly un- 
derline the complaints handling system - are particularly indicative.

\subsection{Educating Employees for Handling Complaints}

The public administration needs to guarantee information for the employees on the significance of handling complaints appropriately and train them appropriately for this purpose. In the private sector, the need for a complaints handling system stems from the fact that a dissatisfied consumer usually goes to the competitors. In the case of negative experience, negative communication that can harm a company is spread "mouth-to-mouth", which can harm a company's financial position.

Negative financial consequences or experience arising from an insufficient effort to satisfy a customer is still of secondary significance in the public administration. One of the reasons is also probably the lack of awareness on the part of the public officials about the need to appropriately handle user complaints. Moreover, there are many officials who do not see themselves as people who need to be there for and help the customers by providing the service. On the contrary, they perceive their position as that of an executor of higher functions or tasks. As they are able to understand the tasks and procedures they are in charge of, they believe that they are more important than the customer. Moreover, they believe that the criteria for the appropriateness of customer relations is merely the legality of the procedure, while all the rest is, from their point of view, irrelevant or something they only have to do if they want to. On the basis of this, customer/user complaints are viewed in general as annoying, unpleasant and time-consuming and are treated with reservation even more so if they believe that the process was carried out within the scope of the legal provisions.

We cannot approve of this approach towards complaints handling as adequate handling of complaints brings numerous benefits for both the public administration and the users of its services. A carefully studied complaint can help the administration improve the quality of administrative services. Besides that, the approach to the handling of complaints - or the handling itself - contributes a lot to the appearance and reputation of the administrative body in the eye of the public and reduces the fears, alienation and frustration of the customers. This is why the system of complaints handling in the administration needs to be designed in such a way that it ensures the provision of appropriate information for the employees, their motivation and appropriate knowledge or education in the field of customer relationships to ensure customer satisfaction with the public services provided.
4 Complaints Pursuant to the General Administrative Procedure Act (ZUP)

\subsection{General Information on Complaints Under ZUP}

The right to complain is a fundamental right of each individual. Regardless of the development of modern complaint mechanisms, a complaint against a decision by the administrative procedure deciding on a right, obligation or legal benefit for an individual or legal entity is a basic institute of democracy and the quality of administrative work. Schuppert (2000: 788-793) defines the administrative procedure as an instrument of the rule of law and democracy, especially in connection with the protection of constitutional rights. Since the right to complain against a decision on the merits of an authority is an important part of the administrative procedure, without any doubt it can be treated as a civil right that reflects the level of democracy in the state. On the basis of the ZUP, the complaint is the only regular legal means for protecting the legality in the administrative procedure.

Each customer in the procedure (i.e. the person who only obtained the status of a customer during the decision-making process at the first instance) has the right to complain against a decision issued at the first instance. However, the customer's right to complain in the sense of the constitutional provision of "the right to legal remedy" must be interpreted in a broader sense. Pursuant to Article 229 of the ZUP, the customer and any other person who believes that a specific act intervenes into their rights or legal benefits is entitled to complain. Nevertheless, a person demanding participation in the process must be able to justify his/her legal interest.

Speaking of the administrative procedure, we must be aware that it does not just apply to the administrative units and ministries but that all the bodies in the public administration must act in compliance with the set rules. This also applies to other state bodies, local bodies and public authority holders when deciding on the rights or legal benefits of natural persons or legal entities in administrative matters. It is also reasonable to apply the rules of the administrative procedure to the "non-administrative bodies" when deciding on matters that fall under civil law concerning the rights and obligations of individuals or organisations, in case such areas are not regulated by a special procedure (e.g. public agencies, public institutions and chambers), meaning that the right to complain can also be exercised against their decisions.

They allow for the possibility that a complaint can be replaced by another legal remedy, since the legislator has the option of excluding complaints as a regular legal remedy if it provides another equally efficient remedy. The right to complain is excluded by the ZUP in certain cases

\footnotetext{
${ }^{2}$ A customer in the administrative procedure can be any natural person or legal entity under private or public law who submitted a request to initiate the procedure or against whom a procedure has been initiated (ZUP, Article 42).
} 
(e.g. Article 230, if the National Assembly or the Government is in charge of adopting decisions). Always, and especially if a complaint is excluded, the legality of the individual and concrete administrative act is (also) supervised by the court in accordance with the constitution of the Republic of Slovenia and because of the principle of the distribution of power and the system of breaks and balances. On the basis of the Administrative Disputes Act (ZUS-1, Official Gazette of the Republic of Slovenia no. 105/2006), this is generally the Administrative Court or the Supreme Court, but it can also be the Social Court or a general district or regional court.

\subsection{The Content and Form of Complaints}

A complaint can be filed in writing or orally, for the record, with the body that issued the decision. This means that it is in the duty of the first instance body to perform a formal test of the complaint - i.e. to verify whether the complaint is allowed and submitted in time and by the person entitled to do so. Furthermore, the first instance body may grant the complaint should it find out that the appellant is right, and will then issue a substitute decision in accordance with Article 240 of the ZUP.

Concerning the reasons for complaining as a consequence of violating the rules of procedure, we must distinguish between the so called non-significant violations, i.e. violations that could not impact the accuracy of the decision and significant violations of procedure. On the basis of Article 237 of the ZUP, these are defined as violations that could significantly impact the legality of the decision issued. It must also be pointed out that the complaints body is also obliged to verify significant violations of the rules of procedure and inappropriate use of material law even if the appellant did not refer to them, since the formal legality of a decision is nonetheless a matter of public interest.

Pursuant to Article 222 of the ZUP, a customer may also lodge a complaint with a second instance authority if the first instance authority failed to issue a decision within the prescribed deadline, whereupon it shall be deemed, on the basis of legal fiction, that the customer's request was rejected. The body's failure to respond does not necessarily mean that it is violating the law but, in any case, such an action is harmful to the customer involved the procedure.

Pursuant to Article 235 of the ZUP, the general deadline for submitting a complaint is within 15 days of serving, however, special provisions can stipulate a different deadline - shorter or longer - for submitting complaints (e.g. the deadline for submitting complaints against a building permit is 8 days). ZUP also gives the right to complain to an indirect participant who has not been invited to participate and not been served a decision. Such a person may demand to be served a decision within the specified deadline on behalf of the customer and may then lodge a complaint within the same deadline as specified for the customer, but only if it is possible to conclude, on the basis of the given circumstances, that they could not know about or anticipate the issue of a decision.

Since a complaint is a suspension legal remedy, a decision may not be executed prior to the termination of the complaint deadline. Exceptionally, it is possible to execute the decision before the adoption of a decision on the complaint if this is explicitly stipulated by a law (that a complaint shall not suspend the execution) or if it is an emergency in the public interest that cannot be postponed or would, if postponed, cause irreparable damage to the customer.

\subsection{Deciding on the Complaint}

The competence for deciding on a complaint against a decision by a first instance body is closely connected to the organisational structure of the public administration. In the case of a complaint, we talk of the so-called administrative instance route, which means that a body at a higher instance shall decide on the complaint since, being a devolutionary legal remedy, it cannot be decided upon by the body that issued the decision in the first instance. Complaints against the decision of a municipal authority are resolved by the mayor, which is criticised by the experts (e.g. Jerovšek et al., 2004) who say that this treatment is inappropriate as these procedures are not separated in practice and it is often the case that the same person prepares the second instance and the first instance decisions.

For the substantial resolving of complaints, the complaints body will adopt one of the following decisions: the complaint is rejected as ungrounded, whereby the decision of the first instance body is confirmed, the decision of the first instance body is cancelled and remanded again to the first instance body or a decision on the merits is adopted by the second instance body. The decision on the complaint must be issued and served to the customer as soon as possible but, in any case, within two months of the date on which the body received the complete complaint.

Unfortunately, the statistical data gathered on the basis of the Rules on the keeping of records of administrative procedures (available annually on the web pages of the Government) cannot give us an answer on whether the use of complaints has improved the handling of administrative procedures. This is because there is only data available on the number of complaints filed and whether or not they have been rejected. For instance, we can establish that approximately 2600 complaints were filed against decisions (in total, about 758,000 ) issued by administrative units in the first instance in year 2006, and only about 150 complaints were immediately rejected. But, more importantly, there is absolutely no data on the type of mistakes made in the first instance and if the same mistakes are recurring. One can only find certain good practices among individual administrative units that have been recorded (http://upravneenote.gov.si/). Namely, in the context of use of CAF or EFQM models of excellence or ISO standards, some administrative units regularly check the deci- 
sions of the complaints bodies on their decisions to avoid repeating the same mishandlings.

\section{Understanding the Complaints Handling System}

Customer complaints are no rarity, although they are (too) often understood and justified simply as (negative) criticism, as happens practically everywhere. They are a so-called bitter pill that is unavoidable, but due to this they are not taken seriously enough. There is more to complaints than just this, however, especially if we look at them from the point of view of development. Through their "grousing" and "nagging", the users of public services deliver different opinions, proposals and ideas on how to improve the process of administrative work. The customer's "efforts" and the filed complaint can also be interpreted as a fact that the customers are not indifferent to the operations of the public administration. Therefore, the customers must be stimulated to co-operate in the future as well. In any case, a complaint is no longer merely a problem and an annoyance but rather a valuable incentive, a suggestion and an opportunity for improvement.

While the issue of complaints handling is given the highest priority in private companies, the public administration has paid very little attention to this problem so far. In companies, the marketing departments thoroughly study each customer complaint. Often, these are even analyzed together with the affected customers or officials with the aim of satisfying the customer, consolidating the bonds with them, ensuring the quality of their products and services, creating a more positive image in the public and taking into account the principle of loyalty to the customers. These reasons should serve as guidance for changing the mentality of public officials.

We must bear in mind that customer satisfaction changes over time. It is very important that it is not only assessed exceptionally but all the time. Without constant monitoring of the quality of services, the organisation cannot satisfy its customers and nor can it operate efficiently in accordance with the element of integral quality. The concept of continuous monitoring and improvement of quality is known in Slovenia to a certain extent, but it is rarely implemented in the everyday operations of individual organisations. More attention is paid to other (according to the managements of the organisations) "more urgent matters" (Koren, 1996: 72).

A complaints handling system, suitable for public administration, comprises a systematic and target oriented functioning of the public administration based on the complaints from the users. It researches the reasons behind the customer dissatisfaction, tackles their complaints, issues instructions for resolving the problems identified and introduces changes in attitude towards the customer relationships and its own operations. On the one hand it would be sensible to separate and on the other to merge, in terms of system and contents, the classic "true" complaints against the administrative procedure and the complaints against the general operation of the public administration in accordance with the Decree on administrative operations and the models of quality or excellence.

This gives rise to the significance of an appropriate collection of information as the basis for the formation of individual activities in the area of customer management. Within the organisations of the public administration, the customers need to be stimulated to give feedback about the perceived attitude or the progress of work in the public administration. The data gathered, the complaints themselves and, above all, the information collected in relation to the complaints must be analysed and evaluated and conclusions must be drawn that will allow for the elimination or reduction of the negative impacts of customer dissatisfaction and the re-establishment of customer satisfaction in relation to the public administration. Issuing or changing instructions in relation to administrative work or customer relationships already constitutes a part of the goals and tasks of the system of complaints management, which should become the priority of the public administration.

\section{Conclusion}

In the current situation of fierce competition in all areas, good and quality work is the best and only guarantee for the existence and development of any activity. This also applies to the public administration, even though it is usually not comparable with the entrepreneurial sector. As a rule, the administration does not have to fear losing customers; however, this is why the need for ensuring and monitoring the quality and efficiency of work is increased and represents a significant social challenge and requirement. Both the ZUP and the Decree on administrative operation bind the administrative bodies to conduct administrative procedures in a correct, professional, friendly and quick manner. In this respect, besides the use of tools, the ZUP and the Decree are the two main instruments for developing the public administration.

The quality of administrative work or the quality of the work of individual officials is often reflected in the number of complaints submitted, which is why these must be treated as a valuable source of information. It is important that the complaints no longer be treated and monitored merely in terms of numbers but also in terms of content, which means in practice that they are considered as important feedback information on the quality of work of the administrative body when implementing corrective and preventive measures, the aim of which is to improve the work of the public administration as a whole. Different complaint systems need to be connected: A responsible attitude on the part of the administrative body towards the complaint submitted by any customer against an administrative decision does not just mean compliance with the provisions of process legislation but also includes the efforts to reduce the number of justified complaints. It includes: 
- the introduction of additional education and training for employees when it is evident from analysis of the causes of complaints that their knowledge is insufficient,

- the introduction of corrective organisational measures, including the rearrangement of employees who are not qualified for the quality management of administrative procedures to other, less demanding positions,

- the introduction of "internal administrative supervision", which, through the inspection of randomly selected administrative matters, discovers the most frequent errors in the management of the administrative procedures, about them or within them with the aim of prevention, and alerts all the employees in the administrative body, etc.

The result of this attitude on the part of the administrative bodies towards the customers' complaints against administrative decisions is therefore the reduction of the number of justified complaints, the increase and strengthening of the trust of society in the legality of the work of the administration and, consequently, the reduction of labour costs for the public administration.

\section{Literature}

Bader, V. M. (1991). Kollektives Handeln: Protheorie kollektiven Handelns und sozialer Ungleichheit, Opladen, FR Germany: Leske \& Budrich 1991.

EIPA (2006): The Common Assessment Framework (CAF), Improving an organisation through self-assessment. Accessible on: http://www.eipa.eu/en/pages/show/\&tid=68 (27.12. 2006).

Jerovšek, T. \& Trpin, G. (eds.). (2004). Zakon o splošnem upravnem postopku s komentarjem, Inštitut za javno upravo pri Pravni fakulteti Univerze v Ljubljani, Nebra, Ljubljana.

Koren, M. (1996). Problematika obvladovanja kakovosti v storitvenih organizacijah, 2. del. Gospodarski vestnik, 36: 71-73, Gospodarski vestnik d.d., Ljubljana.

Kovač, P. (2006). Pravni in sociološki vidiki javnih pooblastil, Fakulteta za upravo, Ljubljana.

Kovač, P. \& Kern-Pipan, K. (2005). Evropski model odličnost EFQM kot optimalno orodje razvoja odlične slovenske javne uprave, Javna uprava, 4: 723-742, Pravna fakulteta Univerze v Ljubljani, Ljubljana.

König, T. (2000). The New Age Movement: Genesis of a High Volume, Low Impact Identity, Dissertation, Department of Social and Political Sciences, European University Institute.

Luhmann, N. ([1984] 1988). Soziale Systeme: Grundriß einer allgemeinen Theorie, Frankfurt a/M, FR Germany: Suhrkamp 1988.

Lorbar, M. \& Stare, J. (1998). Upravno poslovanje 2. Gospodarski vestnik, Ljubljana.

Nemec, T. (2001). Elementi »mehke kakovosti « v državni upravi. Accessible on: http://upravneenote.gov.si/fileadmin/ pageuploads/ue-ljutomer/jpg/Kakovost/Prispevki/ Elementi mehke kakovosti v DU.pdf (25.9.2001).

Nemec, T. (2007). Ali se kakovost v upravi splača? (Uspešnost in stroški kakovosti v upravi). http://upravneenote.gov.si/ fileadmin/pageuploads/ue-ljutomer/jpg/Kakovost/
Prispevki/Ali_se kakovost_v_upravi_izplaca.pdf (23.10.2007).

Schuppert, G. F. (2000). Verwaltungswissenschaft (Verwaltung, Verwaltungsrecht, Verwaltungslehre), Nomos Verlagsgesellschaft, Baden-Baden.

Weber, M. ([1921] 1978). The definition of Sociology and Social Action, in: Max Weber: Economy and Society, Berkeley, CA: University of California Press, 1978: 4-26.

\section{Sources}

Administrative Dispute Act (ZUS-1, Official Gazette of the Republic of Slovenia, nos. 105/2006, 26/2007).

Administrative units (2007). Portal upravnih enot. Accessible on: http://upravneenote.gov.si/ (16.10.2007).

Constitution of the Republic of Slovenia (URS, Official Gazette of the Republic of Slovenia, nos. 42/1997, 66/2002, 24/2003, 69/2004, 69/2004, 68/2006).

Decree on administrative operations (UUP, Decree, Official Gazette of the Republic of Slovenia, nos. 20/2005, 106/2005, 30/2005, 86/2006, 32/2007, 63/2007).

General Administrative Procedure Act (ZUP, Official Gazette of the Republic of Slovenia, no. 24/2006-UPB2, 105/2006ZUS-1).

Ministry of Public Administration (2007a). Ministrstvo za javno upravo. Kakovost. Accessible on: http://e-uprava.gov.si/euprava/javniStran.euprava? pageid $=130$, http://mju.gov.si/index.php?id=203\&type=98 (16.10.2007).

Ministry of Public Administration (2007b). Ministrstvo za javno upravo, Zadovoljstvo strank. Accessible on: http:// mju.gov.si/index.php?id=384\&no cache $=1,((16.10 .2007)$.$) .$

Rules on the keeping of records of administrative procedures (Rules, Official Gazette of the Republic of Slovenia nos. 18/2003, 7/2006).

Janez Stare is Senior Lecturer on the Faculty of Administration, University of Ljubljana, lecturing on Human Resource Management, Leadership and Organisation in the Public Sector. He started his career at as a marketing manager. In 1994, he began working as an Assistant at the Faculty of Administration. He finished a masters degree in Human Resource Development and a $\mathrm{PhD}$ with a dissertation on the role of leadership in public administration. He successfully heads and participates in various research projects from the field of Human Resource Development and Public Administration. In 2006-2007 he headed the project on the Leadership competence model in Slovenian public administration. Since 2006, he is a Chair for Students Affairs at the Faculty of Administration, University of Ljubljana.

Barbara Gruden is working for the Ministry of the Interior of the Republic of Slovenia in the Police and Security Directorate, performing her main activities within the special administrative procedure - gaining the licence to access classified data. She graduated from the Faculty of Administration, University of Ljubljana, and is continuing her studies as a post-graduate student. In co-authorship with Polona Kovač, she has published two articles and she was also the receiver of the faculty's "Prešern's award" for above average achievements. 
Polona Kovač is Senior Lecturer at the Faculty of Administration and the Faculty of Social Work, University of Ljubljana, lecturing on legal regulation of the public administration and administrative procedures. Among other things, she carries out seminars and workshops on quality in the public sector and on the use of the CAF model. She is a jurywoman in the system of the national quality.award (PRSPO). In 2007, she is heading the project on the Development and Establishment of the System for the Assessment of Excellence in Public Administration. She has published numerous expert and scientific articles. She actively attends conferences at home and abroad, mainly on the subjects of public administration reforms, administrative procedures and TQM. 